\title{
Xunzi's Educational Thoughts and Its Enlightenment to Modern Education
}

\author{
Lu Yawei \\ China JiLiang University
}

\begin{abstract}
Xunzi, an important educator in the warring States period of ancient China, put forward many ideas about education. These views play an important role in the development of education in ancient China. The purpose of this paper is to explore the inspiration of Xunzi's educational views to modern education. By means of literature research, this paper studies the concept of Xunzi's education from three aspects: individual, teacher and society, and reaches a conclusion that the development of modern education requires individual efforts of learners, the improvement of educators' quality and the optimization of social education environment.
\end{abstract}

Keywords-Xunzi; Evil Human Nature; The Pre-Qin Period; Educational thought; Modern educational

\section{THE THEORETICAL BASIS OF XUNZI'S EDUCATIONAL THOUGHT-EVIL HuMAN NATURE}

Xunzi was a famous philosopher and politician at the end of the Warring States Period. At the same time, he is also an outstanding educator. He devoted his life to education, teaching and research, and accumulated rich experience in long-term educational practice activities. He formed a unique and innovative education concept and made progress in the development of ancient Chinese education. Made an important contribution.

Xunzi's educational thought is mainly based on the theory of human nature of his "evil human nature" . Xunzi's evil human nature is mainly opposed to Mencius's theory of good nature. Mencius believes that human nature is good, and people are born with benevolence, righteousness, courtesy, wisdom, and four good character. The Xunzi thinks that human nature is evil, and people are naturally interested in profit. He said: "The human nature is evil, and its good is also false. People today are materialistic and profit-seeking." It is believed that people cannot have the qualities of goodness in conformity with feudal ethics and political systems. Human nature is evil. If you do not exercise restraint and the evil nature of the day after tomorrow, it will cause social chaos and have a negative impact on social development. So where does good come from? For this question, he put forward the idea of "change humanity by man-made". "Pseudo" refers to the study and hard work in the future. Here he clarified the important role of education in personal growth and social development, and advocated the use of acquired education to "change humanity by man-made". This point has made a theoretical explanation: "Education is being good at learning from the ancestors." It is not difficult to see that Xunzi hopes to make people do good through acquired education. so that people can be good, and thus cultivate the moral quality of the day after tomorrow. Achieve the ultimate goal of adulthood and sanctification.Xunzi' s understanding of the evil nature of human nature has produced his thought of "change humanity by man-made" and the importance attached to acquired education.Xunzi demonstrated the importance of learning and education from many aspects and put forward his rich educational concept.

\section{XUNZI'S DISCUSSION OF PERSONAL LEARNING METHODS}

Xunzi's view of education can be divided into two categories as a whole: one is how to develop good learning habits and use appropriate learning methods to achieve the purpose of the final adult; the other is the specific methods of education. That is, how to adopt appropriate educational methods in education to change the "evil" in the nature of the educated, so as to train "good" talents with qualified moral qualities that are suitable for the development of the society.

Xunzi said: "I try to think about it all the time, not as much as a moment of learning also." It is not difficult to see from Xunzi's theory that he attaches great importance to learning. It is believed that learning can achieve the accumulation of knowledge and cultivate personal moral character, and realize the transformation from evil to good. Xunzi not only paid attention to the importance of learning in personal development but also put forward the unique methods and ways of personal learning. The following is a carding of Xunzi's learning methods:

\section{A. Clarify the purpose of learning and cultivate interest in learning}

Xunzi believes that learning should first be clear about their own purposes, that is, why to learn? In his opinion, the purpose of learning is to achieve the ultimate ideal of "adulthood" through the cultivation of personal etiquette and moral norms. "that scholar, when he practices it, is called a scholar; when he is dubious, he is a gentleman; when he knows it, he is a sage. From Xunzi's theory, we can see his description of the purpose of learning in different degrees. From the most basic training of "scholars" to the training of "gentlemen", the ultimate training of "saints" to achieve the purpose of "adults". To learn is first to train oneself to be a "scholar" with certain knowledge, and then, through the accumulation of knowledge, to attain the goal of not deceiving oneself internally or outwardly. A "gentleman" who behaves according to certain standards of propriety; a "gentleman" who finally cultivates the highest ideal of "saints" to be "adults." 
Xunzi proposed that learning should be clear about the purpose of learning at the same time, pay attention to the cultivation of personal interest in learning. As for how to cultivate their own interest in learning, he believes that "the way to learn better than others, Longli second." To develop an interest in learning is to find people who are good at what they like. Through the pursuit of sage worship, to promote their own to learn from them, so as to enhance the enthusiasm of autonomous learning.

Xunzi's view of learning to clarify the purpose of learning and cultivate interest in learning, in his "advice to learn" in the chapter has been concentrated in the embodiment. It provides a reasonable methodological support for the study of the students at that time, and at the same time, it has been well reflected and developed in the modern education system. Nowadays, both children's basic education and university higher education pay attention to the cultivation of interest in learning. By encouraging people's interest in learning, improve students' enthusiasm for learning, so as to promote the development of innovative learning.

\section{B. Pay attention to the accumulation and the perseverance of persisting in learning}

Xunzi believes that learning is a gradual process, from nothing to something, from more to less. Therefore, it is important to persist in learning, through accumulated learning, unremitting efforts to achieve the accumulation of knowledge and qualitative change. He proposed, "therefore, if you do not accumulate a small step, you will not reach a thousand li; if you do not accumulate a small stream, you will not be able to form a river or a sea." "it is believed that the accumulation of knowledge requires unremitting efforts and perseverance. Xunzi said, "A horse can not jump ten paces at once." Ten jaded horses do not give up their merits. In addition to the accumulation of daily learning, learning also requires concentration, not too impatient. Xunzi said: "the worm has no claws of the sharp, bones and muscles of the strong, on the earth, drinking water, concentrate on." And put forward the "empty and quiet," that to maintain the heart of the virtual and static, you can achieve clear-mindedness, not one-sidedness hoodwinked. Moreover, by giving play to the thinking function of the mind, we can infer the unknown knowledge from the known knowledge. Xunzi, taking animals as an example, vividly explained the quality that needed to be maintained in his study: he should not only persevere, but also keep his mind free from arrogance and impetuosity, so as to realize the accumulation of knowledge and achieve the goal of learning.

A strong will to learn is an essential part of the learning process. There are many thinkers who advocate this view in traditional Chinese philosophy. There is also no shortage of examples of people who are persistent and assiduous in their studies. In today's society, whether it is in the learning life of young people, or in daily life still adhere to the accumulation of knowledge of other age groups. All of them have well maintained the fine tradition of the Chinese nation of persevering in learning and striving to accumulate knowledge. In the 21 century, when knowledge is changing with each passing day, we need to work harder to increase our personal knowledge base. Through the continuous accumulation of the amount of self-development to achieve a qualitative leap.

\section{Apply what you have learned to achieve the unity of hearing, seeing, thinking, and doing}

Xunzi advocates that learning is a process from perception to application. From hearing, seeing, to thinking, and finally through behavior, to learn in order to apply. He said: "the study of the gentleman also, into the ear, the heart, cloth is four bodies, shape and movement." He believes that complete learning can be divided into three stages, that is, from perception to thinking, and finally applied to real life. Xunzi believes that learning is a process from sensibility to rationality. From the perceptual perception of things to the rational thinking and analysis of things, and through analysis to guide the behavior, into action.

Specifically, first of all, Xunzi affirmed the role of perceptual knowledge in the learning process. Think that only through the actual contact with things, perception of things, in order to achieve a deeper thinking of things. Learning comes from exposure to the objective world. In his "advice to learn" chapter of the study, there is a clear point: "therefore do not climb mountains, do not know the height of the sky also; do not face deep streams, I do not know the thickness of the earth." Secondly, it is not enough for the sense organs to get the preliminary knowledge that "the heart has knowledge". He thinks that the cognitive function of the heart is deeper than that of the senses. It commands the senses, tests the senses, and obtains the function of correct cognition. Therefore, the second stage of learning requires rational thinking and comprehensive analysis of things on the basis of perception of existing things, rising from perceptual knowledge to rational knowledge stage. Thinking plays an indispensable role in it. Finally, Xunzi advocated learning in order to put into practice. He pointed out that the mastery and accumulation of knowledge is ultimately to be applied to reality. The viewpoint of guiding practice with theoretical knowledge is one of the important ideas in the concept of knowing and doing in Chinese traditional philosophy. Xunzi thought, "if you don't smell it, you won't hear it. To see it, to see it without knowing it, to know it without doing it, to learn to do it and stop. "it can be seen that row plays an important role in learning.

Xunzi gives a complete explanation and induction to the knowledge of learning, how to acquire knowledge, how to deal with knowledge, and how to use knowledge. At the end of the pre-Qin and warring States period, the appearance of the idea of knowing and doing with practice as the ultimate goal was one of the important links in the development of education in ancient China. Under the influence of Marxist view of practice, the contemporary students need to pay more attention to the combination of knowledge and practice, learning to apply. Only do more contact with things to obtain perceptual knowledge, in order to better perceptual knowledge for rational analysis and inductive arrangement, so as to sum up the corresponding knowledge points. And the knowledge links the objective world, applies the knowledge to the practice. In order to realize the expansion of personal knowledge and the cultivation of moral character, we can achieve the all-round 
development of human beings by achieving the unity of hearing, seeing, thinking and doing.

\section{THE EXPOSITIONS OF XUNZI'S EDUCATIONAL METHODS}

After discussing Xunzi's learning methods, it is necessary to sort out and sum up his educational methods. Learning method is the way and key point of individual learning and success, and education method is how to analyze how to improve the quality of education in the social background in order to achieve the ultimate goal of education. So as to cultivate the talents needed for social development. Xunzi's emphasis on education and methods is mainly reflected in the emphasis on the educational environment, the affirmation of the role of teachers and the requirements for the teaching profession.

\section{A. Affirming the role of the educational environment in education}

Xunzi attached importance to the influence of educational environment on human learning and advocated that good environment can promote human learning. He affirmed the importance of the educational environment. Xunzi put forward the viewpoint of "change humanity by man-made".That is to say, he affirmed the importance of acquired education. The acquired environment is an important element of education. A good environment can provide a good learning atmosphere in the daily education and learning life, and provide help for the formation of "good" quality in the later period. "The grass grows in the haystack and can be straightened without holding it; when the white sand is in the black bauxite, it becomes as black as the bauxite," he said. Xunzi demonstrated the importance of environment to the growth of things through examples. And he pointed out that the gentleman to settle, must choose a good environment. Therefore a gentleman must choose a good place to live, and a good teacher to go on a study trip, so that one can prevent becoming worse and becoming more upright. "

Environment is an indispensable factor in education and learning practice. The good environment may provide the atmosphere and the space for the learner to ponder and to study. Only in a good learning environment, people can pay more attention to learning. Xunzi saw this point, so he put forward his educational thought in the viewpoint of environmental theory. Therefore, in today's education environment, we have to create a good environment for ourselves for others, shape the quality of the education atmosphere.

\section{B. Affirming the role of educators and strict requirements of teachers}

In Xunzi's view of education, he affirmed the status of teachers and believed that teachers played an indispensable role in educational activities. He said "To have a teacher and to learn from him is one of man's most precious possessions. There is no teacher can follow, is a great difficulty in learning." Xunzi inherited and developed Mencius' thought that monarch and teacher should be called together, and put forward the idea that "The ruler and teacher is the foundation of governance". He thinks that teachers are not only those who impart knowledge, but also those who impart propriety. Teachers play an important role in students' knowledge acquisition and personality cultivation. Therefore, he advocated that students should respect their teachers and respect their teachers.

At the same time, however, Xunzi also put forward strict requirements for educators, pointing out that there are four ways of teaching, "but erudite learning does not confer with them." If you are strict with a teacher, you can be a teacher; if you believe in Jainai, you can be a teacher; if you recite and speak but not to commit a crime, you can be a teacher; if you know little, you can be a teacher. "that is, as educators, we need to meet the four requirements of being a teacher: first, under the condition of being knowledgeable, we still have dignity; second, we have rich life and knowledge experience and a certain amount of lofty beliefs; third, we should have a clear and logical teaching method; Fourth, be good at discovering the truth from the trifle. Xunzi thought that only if the above four basic conditions of being a teacher were satisfied, could he pass on knowledge and moral cultivation methods to the scholars.

Xunzi's positive educational thought of respecting teachers gave great affirmation to the status of educators in ancient China. At the same time, it also provides a reference for the development of education in today's society. Respecting teachers is not only a traditional virtue of famous Chinese, but also a good practice in modern education. Xunzi's strict requirements for educators also remind us that to improve the quality of education, we must first strengthen the personal quality and cultural literacy of educators. A society can only respect and respect teachers in order to promote the benign development of education, and the improvement of educators' comprehensive literacy is also an important key factor to improve the quality of education.

\section{SUMMARY}

Education is the foundation of a nation and an important condition for personal development and social progress. Xunzi was a famous philosopher and educator in the pre-Qin period. He put forward some ideas about learning and education. This thesis takes Xunzi's view of education as the breakthrough point, and analyzes the theoretical basis of Xunzi's educational idea-the evil theory of nature. It summarizes Xunzi's educational purpose of "change humanity by man-made" in order to become a sage.

This article combs the methodology of individual learning in Xunzi's educational view. And combined with the reality of education in today's society, summed up several Xunzi representative of the learning methods can be used for reference. Xunzi believes that the individual in the study should first be clear about the purpose of learning, and cultivate the interest in learning. Then to find their own way of learning, and insist on learning. Finally, through the accumulation of knowledge, the knowledge will be used in daily life. This article also from the social environment and educators start with the actual analysis of Xunzi's view of education. Xunzi emphasized the importance of educational environment and educators' personal accomplishment to educational practice. He thinks that a good educational environment can promote education. Xunzi also pointed out 
that teachers' personal knowledge and moral literacy played a vital role in the development of education.

Although Xunzi's educational thought has been more than two thousand years ago. But some excellent thoughts still play a positive role in the long process of social development and change. Education is still important in today's society. Therefore, we should inherit and develop the excellent traditional educational thought, and try our best to explore and create the educational method of the new era which accords with the trend of the times.

\section{REFERENCES}

[1] Research on Xunzi's Philosophy[D].Lu Shasha.Hebei University 2017. (In Chinese)

[2] Comparison of Mencius and Xunzi's Theory of Human Nature[D]. Meng Hao. Jilin University 2013. (In Chinese)

[3] An Analysis of the Educational Views of Mencius and Xunzi[J]. Tu Chunrong. Language Knowledge. 2013, (02). (In Chinese)

[4] Xunzi's Critique of Mencius's Theory of Goodness[J]. Liang Tao: History of Chinese Philosophy. 2013, (04). (In Chinese)

[5] A Brief History of Chinese Philosophy [M]. Peking University Press, Feng Youlan, 2013. (In Chinese)

[6] New Exploration of Xunzi [M]. Renmin University of China Press, Liao Mingchun, 2013. (In Chinese)

[7] A critical biography of Xunzi [M]. Nanjing University Press, Kong Fanzhan, 1997. (In Chinese) 